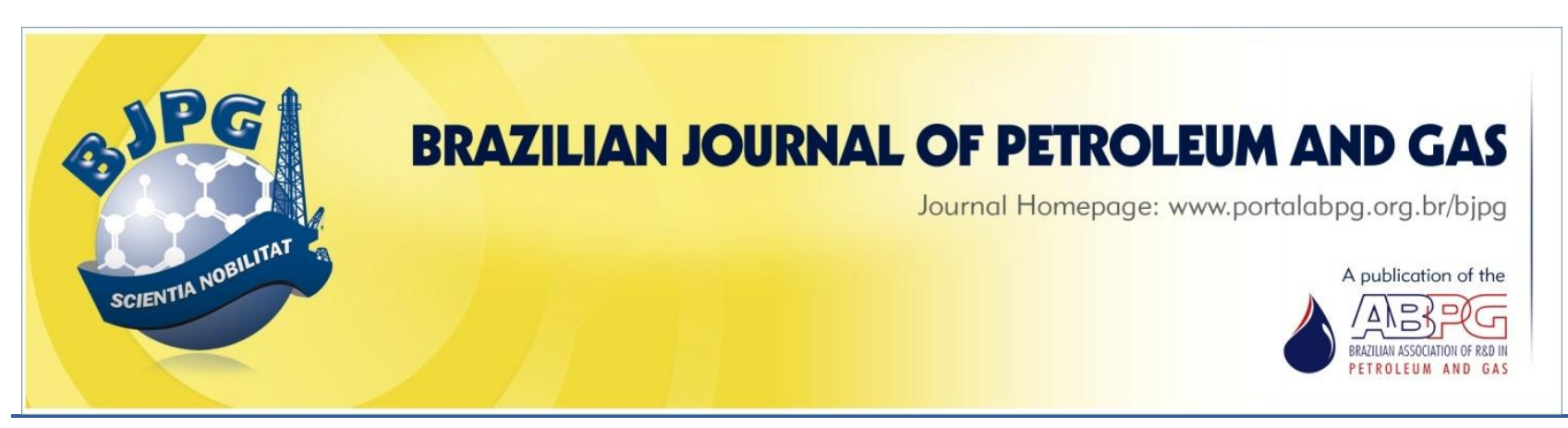

\title{
THE INFLUENCE OF POLYMER FLOODING ON PRODUCED OILY WATER:
} A REVIEW

\author{
${ }^{\text {a }}$ Aguiar, J. I. S. ${ }^{1} ;{ }^{\text {a }}$ Mansur, C. R. E. \\ ${ }^{\mathrm{a}}$ Institute of Macromolecules, Federal University of Rio de Janeiro - UFRJ, Rio de janeiro - RJ, Brazil
}

Received: 24.11.2015 / Revised: 01.02.2016 / Accepted: 02.02.2016 / Published on line: 06.04.2016

\begin{abstract}
The process of chemical enhanced oil recovery, CEOR, involves the injection of substances, such as polymers, that reach the production well after permeating the reservoir. These products affect the stability of the produced oily water after primary separation, making it harder to break down these oil-inwater emulsions. In an attempt to overcome this problem, researchers have studied the influence of polymers on the stability of oily water and have proposed the use of new equipments and chemical additives. This article reviews the studies of the influence of polymer flooding, the most used CEOR technique, on the stabilization and treatment of produced oily water. It is important to understand the influence of polymers on water treatment to avoid interrupting the production of oil and, more importantly, to prevent environment contamination.
\end{abstract}

\section{KEYWORDS}

CEOR; polymer flooding; oily water; emulsion; water treatment

\footnotetext{
${ }^{1}$ To whom all correspondence should be addressed.

Address: Federal University of Rio de Janeiro, Institute of Macromolecules, Laboratory of Macromolecules and Colloids for the Petroleum Industry - Ave. Horácio Macedo, 2030, Cidade Universitária, Rio de Janeiro, RJ, Brazil.

ZIP Code: 21941-598 | Telephone: +55 21 3938-8267 |e-mail: aguiar.jis@ima.ufri.br; celias@ima.ufrj.br doi:10.5419/bjpg2016-0005
} 


\section{INTRODUCTION}

In some countries, while the demand for petroleum is increasing the production is falling due to difficulties in extracting oil from mature fields and finding new fields. For this reason, the use of enhanced oil recovery (EOR) methods is becoming increasingly important (Abidin et al., 2012). Initially, the use of EOR was limited because of its high costs, which made it financially unattractive, but the development of less expensive technologies (Gao \& Sharma, 2012) and the high oil prices in 1980s and 2000s changed this situation.

Before the development of EOR, there were basically two types of oil extraction: primary recovery, relying only on pressure in the reservoir and/or pumps; and secondary recovery, involving on the injection of water (salt or fresh) or an immiscible gas (Correia, 2006). However, these methods are of little effectiveness. For example, primary recovery only manages to extract 10 to $30 \%$ of the oil in the reservoir, while secondary recovery still leaves behind 50 to $55 \%$ of the oil (Sandrea \& Sandrea, 2007; Elraies et al., 2010). It is important to underscore that the words secondary and primary are not correlated with the implementing order, there is no need to start oil recovery using primary recovery or apply secondary recovery before EOR.

Chemical enhanced oil recovery (CEOR), as the name indicates, involves the injection of chemical fluids (polymers, surfactants, and/or alkalines). It can increase the recovery rate by up to $35 \%$ (Nguyen et al., 2012). Because of its good performance, CEOR has become one of the most successful methods to improve recovery from depleted reservoirs and with low pressure (Austad \& Milter, 2000).

The fluids used can contain polymers $(P)$, surfactants $(S)$, alkalis $(A)$, or mixtures of these components. ASP fluids are typically most effective, since each of its components have a specific function.

The function of the polymer consists of raising the viscosity and, hence, the mobility of the crude oil, increasing the volumetric sweep efficiency (Figure 1) (Maheshwari, 2011). The action mechanism of polymers is still under investigation. Although they increase the sweep efficiency, some authors report that the final recovery attained is the same as with water flooding, although much faster (Littmann, 1988). Other researchers, however, argue that polymers can increase the recovery of some types of residual oils (Zhang et al., 2008).

Surfactants are used in EOR to reduce the interfacial tension between water and oil (Donaldson et al., 1985). These molecules are amphiphilic, having a hydrophilic group (head) and a hydrophobic group (tail).

In some cases, a cosurfactant is also used to reduce more the water-oil interfacial tension (Donaldson et al., 1985) when the interfacial tension using only one surfactant is still very high. Generally, medium-chain alcohols are employed in the process (Gradzielski, 1998). The need to use a cosurfactant can be diminished by employing surfactants with branched chains, adding ethylene

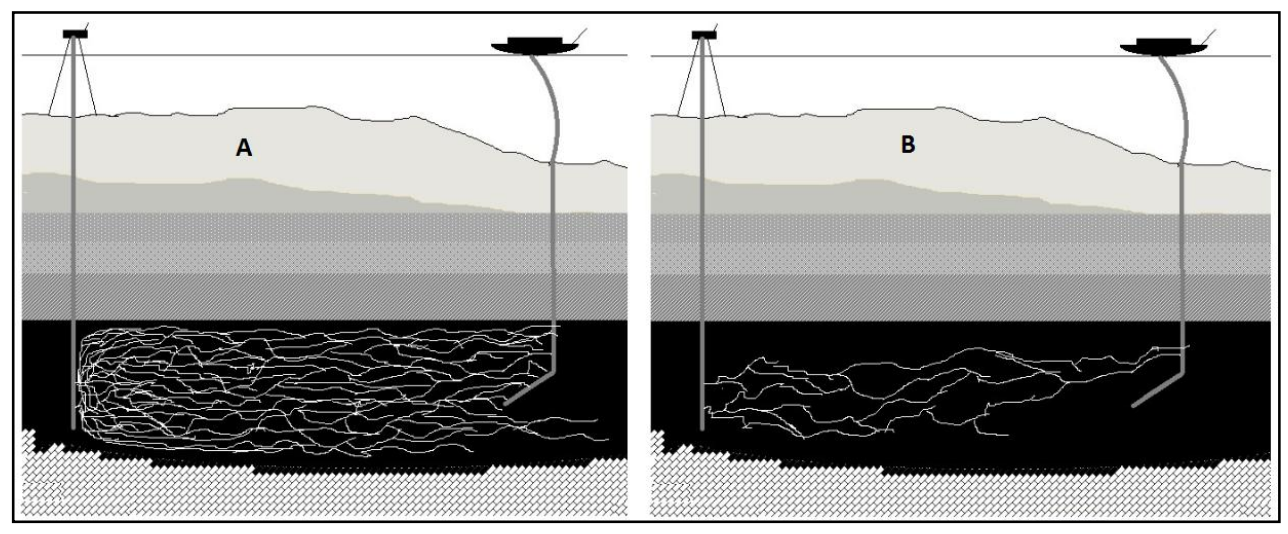

Figure 1. Scheme of polymer flooding $(A)$ and water flooding (B). 
oxide and/or propylene oxide, or mixtures of surfactants with different structures and hydrocarbon chain lengths (Hirasaki et al., 2010).

The way that alkalis act is very complex. For this particular reason, many mechanisms have been proposed involving formation of emulsions, inversion of wettability, and blockage of highly permeable zones (McAuliffe, 1973; Johnson, 1976; Arhuoma et al., 2009). This diversity of theories is related to the differences among crude oils, reservoirs, $\mathrm{pH}$ conditions, salinity, and other criteria (McAuliffe, 1973; Liu, 2008).

One of the most investigated mechanisms is the reduction of the water-oil interfacial tension due to the reaction of the alkaline compounds with the acids present in the oil, such as naphthenic acids, generating a soap (a term use to differentiate it from injected surfactants), which can stabilize the emulsions formed. This action increases the displacement efficiency. The efficiency in reducing the interfacial tension depends on the $\mathrm{pH}$ of the water, the concentration and type of salt, the organic acids present in the solution, and oil, respectively (Cooke et al., 1974).

The components applied in CEOR elute from the well together with the oil and gas. They are sent for a primary treatment, in which the three phases (water, oil, and gas) are separated. However, after this primary separation, the produced water still contains oil droplets, so it needs to be treated further before being discharged or reinjected. Water-soluble polymers remain in the aqueous phase and reach the water treatment station, where they can cause many problems, such as failure of heating equipment and reduced efficiency of hydrocylones and gas flotation units (Deng et al., 2002b; Deng et al., 2005; Zheng et al., 2011).

In response to these problems, some researchers have studied the influence of the CEOR components on the stability of oily water. However, there are very few laboratories equipped and people trained to study this question (Walsh \& Henthorne, 2012). The study of the stability of these emulsions in the presence of the chemicals used for treatment, or even to design new devices to treat produced water is still under investigation. There is also a need to develop new products and technologies that can be used in existing water treatment units.
This review article focuses on the effect of polymers used in CEOR on the stability of emulsions, because:

(i) despite the existence of many studies investigating the action of polymers in CEOR on the stability of oily water, a definitive conclusion is yet to be reached on the most important action mechanism of a flocculant in the presence of the polymers used in CEOR;

(ii) although partially hydrolyzed polyacrylamide (HPAM) is the main polymer studied (Cubillos et al., 2015), because of the widespread application of CEOR, many other polymers are being investigated for this purpose, such as hydrophobically modified polyacrylamides (Zhang et al., 2013; Zhong et al., 2007; Dupuis et al., 2012), terpolymers (Liu et al., 2012; Zhang et al., 2010) and copolymers containing 2-acrylamido-2methylpropane sulfonic acid (AMPS) (Ye et al.,2013; Parker and Lezzi, 1993; Aggour, 1994), so their effects on produced water need to be studied; and

(iii) polymer flooding is the most common EOR method currently in use (Lake $\&$ Walsh, 2008).

\section{INFLUENCE OF POLYMER FLOODING ON THE STABILITY OF OIL-IN-WATER EMULSIONS}

To determine the influence of this technique, various factors must be determined, such as the composition and oil concentration of the produced water, the form of producing the emulsions, the polymer and its concentration, and the equipment that will be used.

\subsection{Produced water composition}

One of the first parameters to be defined is the determination of the salts and their concentrations. This is important because salts can cause the precipitation of polymers and influence the net electric potential difference between the surface of the dispersed particles (oil droplets) and the medium, affecting the flocculant's efficiency.

For example, partially hydrolyzed polyacrylamide performs well as a thickener due to the presence of anionic charges along the polymer 
Table 1. Composition of salts in synthetic produced waters.

\begin{tabular}{|c|c|c|c|c|c|c|c|c|c|}
\hline \multirow{2}{*}{ Author } & \multicolumn{9}{|c|}{ Salt } \\
\hline & $\mathrm{CaCl}_{2} .2 \mathrm{H}_{2} \mathrm{O}$ & $\mathrm{MgCl}_{2} .6 \mathrm{H}_{2} \mathrm{O}$ & $\mathrm{KCl}$ & $\mathrm{NaCl}$ & $\mathrm{Na}_{2} \mathrm{SO}_{4}$ & $\mathrm{NaHCO}_{3}$ & $\mathrm{Na}_{2} \mathrm{CO}_{3}$ & $\mathrm{CaCl}_{2}$ & $\mathrm{MgCl}_{2}$ \\
\hline $\begin{array}{c}\text { Argillier et al. } \\
\text { (2014) }\end{array}$ & $6.6 \mathrm{~g} / \mathrm{L}$ & $5.5 \mathrm{~g} / \mathrm{L}$ & $3.0 \mathrm{~g} / \mathrm{L}$ & $65 \mathrm{~g} / \mathrm{L}$ & $0.2 \mathrm{~g} / \mathrm{L}$ & - & - & - & - \\
\hline $\begin{array}{l}\text { Argillier et al. } \\
\text { (2014) }\end{array}$ & $10.0 \mathrm{~g} / \mathrm{L}$ & $6.0 \mathrm{~g} / \mathrm{L}$ & $0.6 \mathrm{~g} / \mathrm{L}$ & $85 \mathrm{~g} / \mathrm{L}$ & $1.3 \mathrm{~g} / \mathrm{L}$ & - & - & - & - \\
\hline $\begin{array}{l}\text { Deng et al. } \\
\text { (2002b) }\end{array}$ & - & $0.0355 \mathrm{~g} / \mathrm{L}$ & - & $1.523 \mathrm{~g} / \mathrm{L}$ & $0.0105 \mathrm{~g} / \mathrm{L}$ & $2.820 \mathrm{~g} / \mathrm{L}$ & $0.1687 \mathrm{~g} / \mathrm{L}$ & $0.0569 \mathrm{~g} / \mathrm{L}$ & - \\
\hline $\begin{array}{l}\text { Di et al. } \\
\text { (2001) }\end{array}$ & - & $0.0007 \%$ & - & $0.1995 \%$ & $0.0001 \%$ & $0.3024 \%$ & $0.0171 \%$ & $0.0002 \%$ & - \\
\hline $\begin{array}{l}\text { Wang et al. } \\
\text { (2011) }\end{array}$ & - & - & - & $1600 \mathrm{mg} / \mathrm{L}$ & $40 \mathrm{mg} / \mathrm{L}$ & $2600 \mathrm{mg} / \mathrm{L}$ & $300 \mathrm{mg} / \mathrm{L}$ & - & $40 \mathrm{mg} / \mathrm{L}$ \\
\hline $\begin{array}{c}\text { Gao et al. } \\
\text { (2011) }\end{array}$ & - & $321 \mathrm{mg} / \mathrm{L}$ & - & $7208 \mathrm{mg} / \mathrm{L}$ & - & $1607 \mathrm{mg} / \mathrm{L}$ & - & $283 \mathrm{mg} / \mathrm{L}$ & - \\
\hline $\begin{array}{l}\text { Li et al. } \\
\text { (2014) }\end{array}$ & & & & $1600 \mathrm{mg} / \mathrm{L}$ & $40 \mathrm{mg} / \mathrm{L}$ & $2600 \mathrm{mg} / \mathrm{L}$ & $300 \mathrm{mg} / \mathrm{L}$ & $40 \mathrm{mg} / \mathrm{L}$ & $40 \mathrm{mg} / \mathrm{L}$ \\
\hline $\begin{array}{c}\text { Guolin et al. } \\
\text { (2008) }\end{array}$ & & $0.143 \mathrm{~g} / \mathrm{L}$ & $0.011 \mathrm{~g} / \mathrm{L}$ & $1.9 \mathrm{~g} / \mathrm{L}$ & $0.062 \mathrm{~g} / \mathrm{L}$ & $1.544 \mathrm{~g} / \mathrm{L}$ & & $0.035 \mathrm{~g} / \mathrm{L}$ & \\
\hline
\end{tabular}

chain, which by repulsion increases the polymer's radius of gyration and the solution's viscosity (Stokes, 1997). However, the hydrolysis degree cannot be too high because this makes the polymer more sensitive to salinity, since electrolytes can have a shielding effect, making the carbon-carbon bonds free and diminishing the polymer's hydrodynamic volume and efficacy (Donaldson et al., 1985). The same effect can occur when the hydrolysis degree is low but the salinity is high (Donaldson et al., 1985). Although high ion concentrations impair the performance of this polymer, fluids with low salinity are potentially damaging to reservoirs, so salinity parameters need to be established for injection water (Donaldson et al., 1985). Furthermore, the content of the injection water is related closely to the salt concentration of the produced water, so it is necessary to evaluate whether this water will interact with the formation water, which can either have different salts or the same salts but in different concentrations than the injected water. Di and collaborators conducted tests to assess the salt composition of injected and produced water (Di et al., 2001). They found that the produced water contained an additional salt to those found in the injection water, sodium carbonate, and that the proportions of the other salts were significantly different.

The literature contains reports of various compositions of synthetic brines used to study the behavior of produced water. Table 1 lists examples of the synthetic produced waters from various articles.

Fine solids may also be present in the medium and they may help stabilize the emulsion (Yan, Masliyah, 1996). These solids can come from the rock formation, corrosion products, bacteria, and asphaltenes (Motta et al., 2013).

\subsection{Oil concentration and droplet size in produced oily water}

The oil concentration and droplet size in produced water can be related to the shear force between the oil and water phases during production of crude oil and the contents of natural and synthetic emulsifiers present in the emulsion. It is important to formulate a synthetic oily water for testing with a determined oil concentration and droplet size distribution, according to the treatment process of interest, since the treatment can have limitations regarding these two parameters. For example, while hydrocycloning can remove droplets measuring $10-15 \mu \mathrm{m}$, gas-induced flotation with addition of chemicals can remove droplets in the range of 3-5 $\mu \mathrm{m}$ (Frankiewicz, 2001).

Various oil concentrations and initial droplet sizes in oily water for treatment have been reported in the literature, mainly between 250 and 2,000 mg/L and 1 to $100 \mu \mathrm{m}$, respectively (Wang et al., 2011, Qi et al., 2013). 


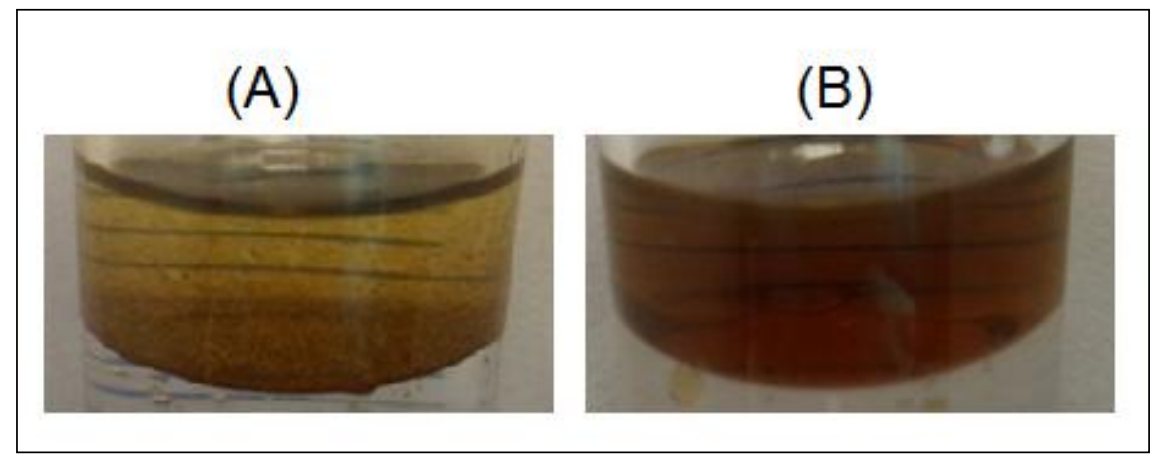

Figure 2. Separated organic phase after oil extraction from a w/o emulsion using (A) pentane and (B) toluene.

\subsection{Preparation of oily water samples}

Generally, the preparation of an oily water sample is relatively simple, but it is very important to describe it in detail, because this can interfere with the concentration of oil incorporated in relation to that introduced, and modify the droplet size distribution. Furthermore, the preparation procedure is more important when the emulsion contains polymers, since they can degrade depending on the shear force used.

For example, in one study an emulsion was prepared containing polymers and shear was applied at 20,000 rpm for $6 \mathrm{~min}$ (Di et al., 2001), which caused considerable degradation of the polyacrylamide. Other researchers have prepared emulsions of salt water and oil by applying high shear rates before diluting the solutions with polymers, performing only one agitation after this procedure (Deng et al. 2002b, Wang et al., 2011, Wang et al., 2014).

Another important point is the way of extracting the oil from the water. In studies made by our group (Magalhães et al., 2015), it was observed that caution is necessary in choosing the solvent for this procedure. Figure 2 shows the organic part after extraction of oil using pentane (Figure 2A) and toluene (Figure 2B). As can be seen, the use of pentane for extraction caused the formation of precipitates, which also can be happen when using hexane, since crude oil typically contains components that are not soluble in these solvents, like asphaltenes. These precipitates can interfere in quantification of the oil concentration.

\subsection{Influence of polymers}

The injection of polymers can generate produced water that is at least twice as viscous as conventional produced water (Walsh \& Henthorne, 2012). The presence of polymers in the produced water can be quantified, for example, by colloidal titration or UV-vis spectrophotometry (Fang et al., 2013; Al Momani \& Örmeci, 2014). These polymers can have a molecular mass range of 7 to 10 million daltons (Al Kalbani et al., 2014) and can alter the efficiency of various water treatment processes. The influence of these polymers varies based on their type and concentration. For example, at low concentrations, hydrolyzed polyacrylamide can promote flocculation of oil droplets, but at high concentrations can hamper these same processes (Walsh \& Henthorne, 2012).

A recent study investigated the influence of three different polymers on the flotation of o/w emulsions containing $200 \mathrm{ppm}$ of oil and $750 \mathrm{ppm}$ of polymer (Argillier et al., 2014). The polymers employed were the traditional HPAM with high molecular weight, sulfonated polyacrylamide (SPAM), and sulfonated hydrolyzed polyacrylamide (SHPAM). Analysis of the oil concentration in the induced gas flotation cell in function of time revealed a large increase in the emulsion's stability when it contained polymers. The three emulsions containing polymers had oil concentrations greater than 80 ppm after 60 seconds of testing, while the concentration in the emulsion without polymers reached zero ppm. A factor that could have impaired the flotation is the difficulty in promoting gas bubble dispersion in the presence of polymers (Walsh \& Henthorne, 2012). 
However, in another study using concentrations of 200 and 400 ppm of a HPAM having a molecular weight of $3 * 10^{6}$ daltons and a hydrolysis degree of $30 \%$, with or without a surfactant and alkali, the emulsion was less stable, meaning the polymer had a flocculating effect (Di et al., 2001). The results of this same study indicated that polymers can be adsorbed at the water-oil interface and compete with surfactants for this space.

In 2002, Deng and collaborators showed that polyacrylamide has two effects, it can either facilitate or hinder flocculation, depending on the concentration in the medium (Deng et al., 2002b). Utilizing concentrations of $2000 \mathrm{mg} \mathrm{L}^{-1}, 1000 \mathrm{mg} \mathrm{L}^{-1}$, and $500 \mathrm{mg} \mathrm{L}^{-1}$ of oil, alkali and surfactant, respectively, the oil content and viscosity of the oily water were evaluated with variation of the HPAM concentration. The authors observed that at concentrations below $1000 \mathrm{mg} \mathrm{L}^{-1}$, the polymer favored flocculation, with minimum oil concentration resulting from using $400 \mathrm{mg} \mathrm{L}^{-1}$, while at a concentration of $1200 \mathrm{mg} \mathrm{L}^{-1}$, the oil content increased. The polymer also did not produce a linear effect when the oily water contained $800 \mathrm{mg} \mathrm{L}^{-1}$ of alkali and variable surfactant concentrations. Use of $400 \mathrm{mg} \mathrm{L}^{-1}$ of HPAM produced the lowest oil content for all the surfactant concentrations tested ( 0 to $600 \mathrm{mg} \mathrm{L}^{-1}$ ), followed by the polymer concentrations of $200 \mathrm{mg}$ $\mathrm{L}^{-1}$ and $600 \mathrm{mg} \mathrm{L}^{-1}$. However, the oil concentrations using 200 and $400 \mathrm{mg} \mathrm{L}^{-1}$ were close and the authors did not present the standard deviations (Deng et al., 2002b). The results also showed that the HPAM made the zeta potential more negative and increased the interfacial elasticity, making coalescence of the oil droplets more difficult (Deng et al., 2002b).

Ma et al. (2013) studied the influence of a polymer on the stability of an oily wastewater from the Shengli Oil Production Plant. They compared the differences using one medium (A) with $40 \mathrm{mg} / \mathrm{L}$ of polymer and another (B) without this viscosifier. They reported that on the first day there was no significant difference between the separation efficiency of the two streams. However, as time passed, the separation of current B became greater, reaching approximately $93 \%$ on the fifth day in relation to the first, while the result for current A was only $62 \%$.
The authors explained the small difference at the start by the flotation of large oil droplets. Since the difference in viscosity of the two currents was small $(1.02 \mathrm{mPa} s$ for sample $A$ and $0.84 \mathrm{mPa} s$ for sample B), they considered viscosity to be an important factor for the difference in separation efficiency on the following days. Droplet size was also considered important since on the second day of separation the sizes of the droplets from current A were for the most part smaller than $10 \mu \mathrm{m}$, while for current $B$ the size range was $10 \mu \mathrm{m}$ to $100 \mu \mathrm{m}$. According to the authors, this significant size difference was not found at the start of separation, meaning that the viscosifier used for polymer flooding hampers coalescence of the droplets, resulting in the size difference on the second day. This difficulty is likely not related to the difference in electrostatic repulsion, since the zeta potential of sample A was $-37.6 \mathrm{mV}$ and for sample $B$ it was - $37.9 \mathrm{mV}$ (similar values). Thus, they listed other possibilities for the negative influence of polymers on droplet coalescence: reduced frequency of collision of droplets due to the increased viscosity; formation of a tight and elastic adsorption layer due to adsorption of the polymer in the oil droplets; and action of the polymer as a steric barrier (Ma et al., 2013).

The authors also evaluated how viscosity influences the gravitational separation in function of droplet size. They observed that the more viscous the wastewater, the greater was the size of the recovered oil droplets, i.e., the larger droplets have a greater facility to reach the surface. They also assessed the effect of temperature on the emulsion's stability $\left(23{ }^{\circ} \mathrm{C}\right.$ and $\left.55{ }^{\circ} \mathrm{C}\right)$. Although droplets larger than $100 \mu \mathrm{m}$ were produced at the higher temperature but were not present at the lower one, droplets between 1 to $10 \mu \mathrm{m}$ continued to predominate, probably because despite the greater number of collisions between droplets at the higher temperature, these shocks were not effective in causing coalescence due to the polymer's presence (Ma et al., 2013).

Finally, the authors studied the effect of an efficient flocculant, which modified the zeta potential from $-37.6 \mathrm{mV}$ to $-33.7 \mathrm{mV}$, leading the authors to suggest that the spatial stability, rather than electrostatic stability, is the main factor for the stability of wastewaters containing polymers (Ma et al., 2013). 
In another study, Deng et al. (2005) tested cationic flocculants in oily water containing alkali, surfactant and HPAM. Although the oil concentration in the water declined at certain flocculant concentrations, they observed the formation of viscous sediments due to the reaction of the flocculants with HPAM. Besides this, they also observed sorption of the oil droplets in the sediments, leading them to conclude that flocculation is not a good method to treat produced water from ASP flooding in the Daqing oilfield.

Zhao et al. (2008) investigated the influence of HPAM when using a typical inorganic flocculant, polyaluminum chloride (PAC), and a cationic polyacrylamide at different temperatures. They observed that the efficiency of the PAC increased with rising temperatures, while the efficiency of the cationic polyacrylamide declined with rising temperatures, probably by increasing the probability of reaction with the HPAM and diminishing the efficiency of bridge flocculation. In comparing optimal flocculant concentrations at each temperature $\left(30,33,37\right.$, and $\left.40{ }^{\circ} \mathrm{C}\right)$, i.e., the concentration that performed the best, they observed that using 100 and $600 \mathrm{mg} / \mathrm{L}$ of HPAM, the PAC had greater fluctuations at each temperature, while the optimal dose of the cationic polyacrylamide was more stable, with variations only at $40^{\circ} \mathrm{C}$.

Gao et al. (2011) analyzed an organic flocculant and did not observe any reaction with HPAM. They tested the performance in jar tests of a dithiocarbamate-type flocculant (DTC) at different HPAM concentrations ( 0 to $900 \mathrm{mg} / \mathrm{L}$ ) with oily water samples containing 250 to $300 \mathrm{mg} / \mathrm{L}$ of oil. Without addition of HPAM, $5 \mathrm{mg} / \mathrm{L}$ of flocculant managed to reduce the oil content to $27 \mathrm{mg} / \mathrm{L}$, but with addition of HPAM this concentration was higher than $80 \mathrm{mg} / \mathrm{L}$. The difference in residual oil concentration between the oily waters with and without polymer declined until there was no difference with $20 \mathrm{mg} / \mathrm{L}$ of the flocculant. When using $30 \mathrm{mg} / \mathrm{L}$ of DTC, the residual oil concentration was below $10 \mathrm{mg} / \mathrm{L}$. Besides showing that this flocculant is a good possibility for treating oily water containing polymer, the authors observed no reduction in HPAM after flocculation, indicating the absence of a reaction between the HPAM and DTC (Gao et al., 2011).
Zhang and collaborators (2015), seeking to achieve less viscous flocs, tested a nonionic polymer (polyoxyalkylated polyethyleneimine - PEI) compared with a cationic polyacrylamide (PoAC). They used an oily wastewater (oil concentration near $5,000 \mathrm{mg} / \mathrm{L}$ ) from an offshore oilfield in China, with an HPAM $(280 \mathrm{mg} / \mathrm{L})$. When evaluating the influence of the temperature $\left(30-60{ }^{\circ} \mathrm{C}\right)$ of these two flocculants at a concentration of $300 \mathrm{mg} / \mathrm{L}$ they did not observe an influence on the performance of the PoAC, but did observe a strong effect on the efficiency of the PEl, which only managed to reduce significantly the oil concentration at temperatures higher than $45^{\circ} \mathrm{C}$. They also tested the dose effect at $60{ }^{\circ} \mathrm{C}$ and observed that at low concentrations the efficiency of the PoAC was greater, reaching $40 \mathrm{mg} / \mathrm{L}$ of oil with a dose of $200 \mathrm{mg} / \mathrm{L}$, while the $\mathrm{PEI}$ required 400 $\mathrm{mg} / \mathrm{L}$ to reach the same amount. They also reported that, depending on the flocculant, there can be different optimal rotation and times for flotation and that the flocs formed with PEI were less viscous. They suggested that the flocculation when using PoAC works by electrostatic charge neutralization and bridging, while PEI works by demulsification. They also cited the results of Aguiar and collaborators showing that copolymers containing ethylene oxide and propylene can be used as demulsifiers of water-in-oil emulsions and can displace asphaltenes, which are natural surfactants (Aguiar et al., 2013). Based on these findings and also on the results of variation of the interfacial tension and interfacial dilational modulus with temperature, the authors concluded that PEI works by demulsification (Zhang et al., 2015).

In the previous year, Duan et al. (2014) tested the efficiency of separating oil from water in wastewater containing HPAM of various products containing polyethyleneimine with different concentrations of ethylene oxide and propylene oxide (both diblock and triblock copolymers). They reported that temperature is an important factor for all six products based on polyethyleneimine, with efficiency increasing with rising temperature. However, temperature did not affect the performance of the copolymer made from chloroepoxy propane and dimethylamine. The authors correlated the different efficiency of the products with the hydrophilic-lipophilic deviation (HLD): when the temperature increased, the HLD was shifted to zero and the stability of the 
emulsion with oil concentration lower than 5,000 $\mathrm{mg} / \mathrm{L}$ diminished. They also explained the low efficiency of one of the products tested by its high hydrophilicity (Duan et al., 2014).

Discovering new flocculants is a complex task, since this product must have various attributes to produce good and fast results. Among the desirable results are: the effectiveness at low doses to occupy a reasonable volume; no formation of highly viscous flocs; low cost; and wide concentration range with similar effect, since fluctuations can occur under field conditions. Figure 3 shows photos of the surface of oily water samples 30 minutes after applying a flocculant in different concentrations. It can be seen that concentration affected significantly the formation of flocs in these cases, principally at the concentration of $10 \mathrm{ppm}$ in relation to $50 \mathrm{ppm}$. The behavior expected of a good flocculant is to maintain efficiency and control the formation of flocs, at different concentration ranges.

Another important factor in determining the stability of oily water is the presence of rock particles, which need to be separated from the water, particularly when destined for reinjection. In this respect, Li et al. (2014) studied the influence of laponite on the stability of produced water containing HPAM. They showed that laponite in the presence of a polymer (100 to $600 \mathrm{mg} / \mathrm{L}$ ) can make the zeta potential more negative, diminishing the interfacial tension and making the emulsion more stable. The authors indicated the existence of a synergetic effect between polymer and laponite, favoring the emulsion's stability. This effect depends on the laponite concentration, because at high concentrations it can favor flocculation. They also observed the formation of aggregates by means of optical microscopy. The authors could have clarified the synergetic effect if they had explained the tests performed with variation of laponite without the polymer.
As mentioned, the polymers used for CEOR can impair flotation and also the efficiency of filtration by membranes and hydrocylones (Argillier et al., 2014; Zheng et al., 2011; Guolin et al., 2008). In the case of membranes, polymers can affect their permeability and cause fouling (Guolin et al., 2008). In hydrocylones, in turn, the increased viscosity of the medium results in higher viscous resistance and in the decline of the peak value of tangential-velocity profiles, diminishing the equipment's efficiency (Liancheng et al., 2007; Ren et al., 2012). Therefore, it is important to study new technologies to meet wastewater treatment demands.

For example, Liu et al. (2005) proposed a type of double-cone air sparged hydrocyclone and conducted experiments using water containing oil and polymer concentrations between 550-650 $\mathrm{mg} / \mathrm{L}$ and $300-450 \mathrm{mg} / \mathrm{L}$, respectively. They attained oil removal efficiencies of up to $90 \%$. In turn, Wang and collaborators proposed a flat polyvinylidene fluoride membrane and found that the technique of membrane ultrafiltration was effective (Wang et al., 2014). Furthermore, Deng and collaborators proposed a novel crossflow oilwater separator that managed to reduce the oil concentration to levels below $100 \mathrm{mg} / \mathrm{L}$ starting from initial oil concentrations between 870 and $2,946 \mathrm{mg} / \mathrm{L}$. Besides this, they showed that the produced water from a well in the Daqing oilfield with utilization of water flooding had lower viscosity and droplet size approximately 10 times larger than the produced water from another well in the same field using polymer flooding (Deng et al., 2002a).

Finally, beside the difficulties found in the present water treatment methods, HPAM is potentially toxic. At high levels $(1 \mathrm{mg} / \mathrm{L})$, it can cause lower microbial activity and bad settleability (Luo et al., 2011). Also, its slow and natural degradation generates toxic monomers (Bao et al.,

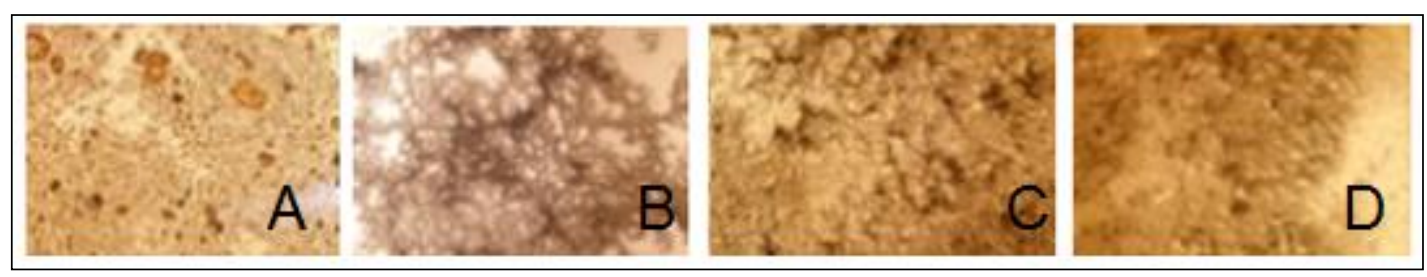

Figure 3. Photos of the surface of oily water samples 30 minutes after applying a cationic polymer in different concentrations- (A) 10 ppm, (B) 50 ppm, (C) 100 ppm and (D) 150 ppm. 
2010). Therefore, it is also important to develop an efficient way to remove HPAM from the aqueous phase and treat it adequately. Various studies have been conducted in this sense, both to remove HPAM from the aqueous phase (Lu \& Wei, 2011; Cao et al., 2011; Liu et al., 2014) and to discharge it without contaminating the environment (Bao et al., 2010; Yongrui et al., 2015). Despite advances in research, Najamudin and colaborators (Najamudin et al., 2014) concluded that there is no appropriate offshore treatment so, for the studied field, the reinjection would be the best option.

\section{CONCLUSIONS}

Many factors can affect laboratory experiments on the stability of oily water containing polymers for CEOR, such as salinity, oil content, droplet size and method of preparing the oily water sample.

It has been well established in the literature that HPAM can act in two ways on the stability of o/w emulsions - by promoting or hampering flocculation - depending on the concentration. Based on this, industries may choose between using different water treatment measures according to the level of polymers from EOR in oily wastewaters.

Polymers can interfere in the stability of oily water in various ways: by adsorbing at the oilwater interface, competing with surfactants and flocculants to form a barrier that hinders coalescence, and having a synergetic effect with laponite, if present, favoring the emulsion's stability; by increasing the viscosity of the medium and thus hindering the collision of oil droplets, requiring larger droplets to cause emergence; and by making the zeta potential more negative, increasing the elasticity of the oil-water interface. At low concentrations, nevertheless, it can facilitate flocculation.

Besides influencing the stability of emulsions, additives containing HPAM can also affect the efficiency of heat exchangers, membranes, flotation units, and hydrocyclones. Therefore, it is important to investigate the influence of polymers injectives in oilfields on the stability of emulsions and the efficiency of equipment to develop technologies to overcome the problems related to its use.

\section{REFERENCES}

Abidin, A. Z.; Puspasari, T.; Nugroho, W. A. Polymers for enhanced oil recovery technology. Procedia Chemistry, v. 4, p. 11-16, 2012. http://dx.doi.org/10.1016/i.proche.2012.06.002

Aggour, Y. A. Thermal degradation of copolymers of 2-acrylamido-2methylpropanesulphonic acid with acrylamide. Polymer degradation and stability, v. 44, n. 1, p. 71-73, 1994.

http://dx.doi.org/10.1016/0141-3910(94)90034-5

Aguiar, J. I. S.; Neto, J. S. G.; Almeida, S.M.; Mansur, C. R. E. Evaluation of the influence of polyoxide-based surfactants on the separation process of model emulsions of asphaltenes using the FTIR-ATR technique. Journal of Applied Polymer Science, v. 128, n. 3, p. 1390-1397, 2013.

Al Kalbani, H.; Mandhari, M. S.; Al-Hadhrami, H.; Philip, G.; Nesbit, J.; Gil, L.; Gaillard, N. Treating back produced polymer to enable use of conventional water treatment technologies. In: SPE EOR Conference at Oil and Gas West Asia. Society of Petroleum Engineers, 2014.

http://dx.doi.org/10.2118/169719-MS

Al Momani, F. A.; Örmeci, B. Measurement of polyacrylamide polymers in water and wastewater using an in-line UV-vis spectrophotometer. Journal of Environmental Chemical Engineering, v. 2, n. 2, p. 765-772, 2014.

http://dx.doi.org/10.1016/j.jece.2014.02.015

Argillier, J.-F.; Henaut, I.; Noik, C.; Viera, R.; Roca Leon, F.; Aanesen, B. Influence of chemical eor on topside produced water management. In: SPE Improved Oil Recovery Symposium. Society of Petroleum Engineers, 2014.

http://dx.doi.org/10.2118/169067-ms

Arhuoma, M.; Yang, D.; Dong, M.; Li, H.; Idem, R. Numerical simulation of displacement mechanisms for enhancing heavy oil recovery during alkaline flooding. Energy \& Fuels, v. 23, n. 12, p. 5995-6002, 2009.

http://dx.doi.org/10.1021/ef900690y

Austad, T.; Milter, J. Surfactant flooding in enhanced oil recovery. Surfactants: Fundamentals and Applications in the Petroleum Industry, $p$. 203-249, 2000.

http://dx.doi.org/10.1017/cbo9780511524844.007 
Bao, M.; Chen, Q.; Li, Y.; Jiang, G. Biodegradation of partially hydrolyzed polyacrylamide by bacteria isolated from production water after polymer flooding in an oil field. Journal of hazardous materials, v. 184, n. 1 , p. 105-110, 2010.

http://dx.doi.org/10.1016/i.jhazmat.2010.08.011

Cao, X. C.; Guo, H. Y.; Li, Y. Y.; Chen, M. The impact of $\mathrm{pH}$ on HPAM removal from Daqing Oilfield produced water using clay and organoclay. In: Advanced Materials Research, p. 2210-2213, 2011.

http://dx.doi.org/10.4028/www.scientific.net/amr.239$\underline{242.2210}$

Cooke Jr, C. E.; Williams, R. E.; Kolodzie, P. A. Oil recovery by alkaline waterflooding. Journal of Petroleum Technology, v. 26, n. 12, p. 1,365-1,374, 1974.

Correia, D. Z. Estudo de misturas poliméricas para recuperação de petróleo. 201f. Tese de doutorado. Universidade Federal do Rio de Janeiro, 2006. (In Portuguese)

Cubillos, H.; Stofferis, M.; Montes, J.; Rodriguez, R.; Prieto, C.; Romero, P.; Blin, N.; Panadero, A. An innovative approach to make HPAM an effective solution to optimize the low salinity ASP application in Caracara Sur Field, Colombia - field case. In: SPE Asia Pacific Enhanced Oil Recovery Conference. Society of Petroleum Engineers, 2015.

Deng, S.; Bai, R.; Chen, J. P.; Jiang, Z.; Yu, G.; Zhou, F.; Chen, Z. Produced water from polymer flooding process in crude oil extraction: characterization and treatment by a novel crossflow oil-water separator. Separation and Purification Technology, v. 29, n. 3, p. 207-216, 2002a. http://dx.doi.org/10.1016/s1383-5866(02)00082-5

Deng, S.; Bai, R.; Chen, J. P.; Yu, G.; Jiang, Z.; Zhou, F. Effects of alkaline/surfactant/polymer on stability of oil droplets in produced water from ASP flooding. Colloids and Surfaces A: Physicochemical and Engineering Aspects, v. 211, n. 2, p. 275-284, 2002b. http://dx.doi.org/10.1016/S0927-7757(02)00281-9

Deng, S.; Yu, G.; Jiang, Z.; Zhang, R.; Ting, Y. P. Destabilization of oil droplets in produced water from ASP flooding. Colloids and Surfaces A: Physicochemical and Engineering Aspects, v. 252, n. 2, p. 113-119, 2005.

http://dx.doi.org/10.1016/i.colsurfa.2004.09.033
Di, W.; Meng, X.; Zhao, F.; Zhang, R.; Yan, C.; Wang, Q.; Liang, H. Emulsification and stabilization of ASP flooding produced liquid. In: SPE International Symposium on Oilfield Chemistry. Society of Petroleum Engineers, 2001. http://dx.doi.org/10.2118/65390-MS

Donaldson, E. C.; Chilingarian, G. V.; Yen, T. F. (Ed.). Enhanced oil recovery, I: fundamentals and analyses. Elsevier, 1985.

Duan, M.; Ma, Y.; Fang, S.; Shi, P.; Zhang, J.; Jing, B. Treatment of wastewater produced from polymer flooding using polyoxyalkylated polyethyleneimine. Separation and Purification Technology, v. 133, p. 160-167, 2014. http://dx.doi.org/10.1016/i.seppur.2014.06.058

Dupuis, G.; Rousseau, D.; Tabary, R.; Argillier, J.F.; Grassl, B. Hydrophobically modified sulfonated polyacrylamides for IOR: correlations between associative behavior and injectivity in the diluted regime. Oil \& Gas Science and Technology-Revue d'IFP Energies Nouvelles, v. 67, n. 6, p. 903-919, 2012. http://dx.doi.org/10.2516/ogst/2012016

Elraies, K. A.; Tan, I. M.; Awang, M. B.; Saaid, I. $M$. B. The synthesis and performance of sodium methyl ester sulfonate for enhanced oil recovery. Petroleum Science and Technology, v. 28, n. 17, p. 1799-1806, 2010.

http://dx.doi.org/10.1080/10916460903226072

Fang, S.; Duan, M.; Xia, Y.; Wang, H.; Li, L. Determination of partially hydrolyzed polyacrylamide in wastewater produced from polymer flooding by colloid titration. Journal of Polymer Engineering, v. 33, n. 4, p. 345-350, 2013. http://dx.doi.org/10.1515/polyeng-2012-0179

Frankiewicz, T. Understanding the Fundamentals of Water Treatment, the Dirty Dozen-12 Common Causes of Poor Water Quality. In: 11th produced water seminar, Houston, TX, Jan. 2001.

Gao, B.; Sharma, M. M. A new family of anionic surfactants for EOR applications. In: SPE Annual Technical Conference and Exhibition. Society of Petroleum Engineers, 2012. http://dx.doi.org/10.2118/159700-MS 
Gao, B.; Jia, Y.; Zhang, Y.; Li, Q.; Yue, Q. Performance of dithiocarbamate-type flocculant in treating simulated polymer flooding produced water. Journal of Environmental Sciences, v. 23, n. 1, p. 37-43, 2011. http://dx.doi.org/10.1016/S1001$\underline{0742(10) 60370-1}$

Guolin, J.; Xiaoyu, W.; Chunjie, H. The effect of oilfield polymer-flooding wastewater on anionexchange membrane performance. Desalination, $v$. 220, n. 1, p. 386-393, 2008.

http://dx.doi.org/10.1016/i.desal.2007.03.010

Gradzielski, M. Effect of the cosurfactant structure on the bending elasticity in nonionic oilin-water microemulsions. Langmuir, v. 14, n. 21, p. 6037-6044, 1998. http://dx.doi.org/10.1021/la980074c

Hirasaki, G. J.; Miller, C. A.; Raney, O. G.; Poindexter, M. K.; Nguyen, D. T. Separation of produced emulsions from surfactant enhanced oil recovery processes. Energy \& Fuels, v. 25, n. 2, p. 555-561, 2010. http://dx.doi.org/10.1021/ef101087u

Johnson Jr, C. E. Status of caustic and emulsion methods. Journal of Petroleum Technology, v. 28, n. 01, p. 85-92, 1976. http://dx.doi.org/10.2118/5561-PA

Lake, L. W.; Walsh, M.P. Enhanced Oil Recovery (EOR) Field Data Literature Search, Technical Report, The University of Texas at Austin, 2008.

Liancheng, R.; Zheng, L.; Gongxiang, Z.; Shihui, W. A comparative study of the flow field of high viscosity media in conventional/rotary hydrocyclones. Petroleum Science, v. 4, n. 1, p. 8185, 2007. http://dx.doi.org/10.1007/BF03186579

Li, F.; Sun, L.; Wang, Y.; Wu, T.; Li, Y. Effect of laponite particles on the emulsion stability of produced water from polymer flooding. Journal of Petroleum Science and Engineering, v. 124, p. 155160, 2014.

http://dx.doi.org/10.1016/i.petrol.2014.10.010

Littmann, W. Polymer flooding. Elsevier, Amsterdam, 1988.

Liu, S. Alkaline Surfactant Polymer enhanced oil recovery process. Dissertation Abstracts International, v. 69, n. 04, 2008.
Liu, S.; Zhao, X.; Dong, X.; Du, W.; Miao, B. Treatment of produced water from polymer flooding process using a new type of air sparged hydrocyclone. In: SPE Asia Pacific Health, Safety and Environment Conference and Exhibition. Society of Petroleum Engineers, 2005.

http://dx.doi.org/10.2118/95343-MS

Liu, X.; Wang, Y.; Lu, Z.; Chen, Q.; Feng, Y. Effect of inorganic salts on viscosifying behavior of a thermoassociative water-soluble terpolymer based on 2-acrylamido-methylpropane sulfonic acid. Journal of Applied Polymer Science, v. 125, n. 5, p. 4041-4048, 2012.

http://dx.doi.org/10.1002/app.36745

Liu, Y. X.; Sui, X. W.; Huang, J. H.; Zhu, Y. Z.; Cao, G.; $W$ U, Z. K. Removal polyacrylamide from oil recovery wastewater by $\gamma$-Fe2O3 magnetic particles. In: Advanced Materials Research, v. 852, p. 32-35, 2014.

http://dx.doi.org/10.4028/www.scientific.net/AMR.852.32

Lu, M.; Wei, X. Treatment of oilfield wastewater containing polymer by the batch activated sludge reactor combined with a zerovalent iron/EDTA/air system. Bioresource technology, v. 102, n. 3, p. 2555-2562, 2011.

http://dx.doi.org/10.1016/i.biortech.2010.11.103

Luo, Y.-L.; Yang, Z. H.; Xu, Z. Y.; Zhou, L. J.; Zeng, G. M.; Huang, J.; Xiao, Y.; Wang, L. K. Effect of trace amounts of polyacrylamide (PAM) on long-term performance of activated sludge. Journal of hazardous materials, v. 189, n. 1, p. 69-75, 2011. http://dx.doi.org/10.1016/i.jhazmat.2011.01.115

Ma, B.; Gao, B.; Yue, Q. Study on emulsification stability of wastewater produced by polymer flooding. Journal of Petroleum Science and Engineering, v. 110, p. 27-31, 2013. http://dx.doi.org/10.1016/i.petrol.2013.08.044

Magalhães, J. R.; Aguiar, J. I. S.; Costa, J. A.; Mansur, C. R. E. Avaliação da influência da massa molar, concentração e carga iônica de polímeros à base de poliacrilamida como floculantes no tratamento de águas oleosas. In: XXXXVI Jornada Giulio Massarani de Iniciação Científica, Tecnológica, Artística e Cultural UFRJ, 2015. (In Portuguese) 
Maheshwari, Y. K. A comparative Simulation study of chemical EOR methodologies (alkaline, surfactant and/or polymer) applied to Norne Field E-Segment. 125 sheets, Master Thesis, Department of Petroleum Engineering and Applied Geophysics, Norwegian University of Science and Technology, 2011.

McAuliffe, C. D. Oil-in-water emulsions and their flow properties in porous media. Journal of petroleum technology, v. 25, n. 06, p. 727-733, 1973. http://dx.doi.org/10.2118/4369-PA

Motta, A. R. P.; Borges, C. P.; Kiperstok, A.; Esquerre, K. P.; Araujo, P. M.; Branco, L. P. N. Tratamento de água produzida de petróleo para remoção de óleo por processos de separação por membranas: revisão. Engenharia Sanitária e Ambiental, v. 18, n. 1, p. 15-26, 2013. http://dx.doi.org/10.1590/S1413-41522013000100003

Najamudin, K. E.; Nor, H. H.; Salleh, I. K.; Hsia, I. C. C.; Yosof, M. Y.; Sedaralit, M. F. Chemical EOR produced water management at Malay Basin Field. In: Offshore Technology Conference-Asia. Offshore Technology Conference, 2014.

http://dx.doi.org/10.4043/24804-MS

Nguyen, D.; Sadeghi, N.; Houston, C. Chemical interactions and demulsifier characteristics for enhanced oil recovery applications. Energy \& Fuels, v. 26, n. 5, p. 2742-2750, 2012.

http://dx.doi.org/10.1021/ef201800b

Parker, W. O.; Lezzi, A. Hydrolysis of sodium-2acrylamido-2-methylpropanesulfonate copolymers at elevated temperature in aqueous solution via 13 C NMR spectroscopy. Polymer, v. 34, n. 23, p. 4913-4918, 1993. http://dx.doi.org/10.1016/00323861(93)90018-6

Qi, W.-K.; Yu, Z.-C.; Liu, Y.-Y.; Li, Y.-Y. Removal of emulsion oil from oilfield ASP wastewater by internal circulation flotation and kinetic models. Chemical Engineering Science, v. 91, p. 122-129, 2013. http://dx.doi.org/10.1016/i.ces.2013.01.020

Ren, L. C.; Meng, J.; Lei, Z. Z.; Wang, J. H. Effect of viscosity on the separation ability of a hydrocyclone. In: Applied Mechanics and Materials, v. 233, p. 7-10, 2012. http://dx.doi.org/10.4028/www.scientific.net/AMM.233.7
Sandrea, I.; Sandrea, R. Global Oil Reserves-1: Recovery factors leave vast target for EOR technologies. Oil and Gas Journal, v. 105, n. 41, p. 44, 2007.

Stokes, R. J.; Evans, D. F. Fundamentals of interfacial engineering. New York: John Wiley \& Sons, 1997.

Walsh, J.; Henthorne, L. Challenges of Water Treating for Chemical Enhanced Oil Recovery. Oil \& Gas Facilities, p. 9-14, 2012.

Wang, B.; Wu, T.; Li, Y.; Sun, D.; Yang, M.; Gao, Y.; Lu, F.; Li, X. The effects of oil displacement agents on the stability of water produced from ASP (alkaline/surfactant/polymer) flooding. Colloids and Surfaces A: Physicochemical and Engineering Aspects, v. 379, n. 1, p. 121-126, 2011. http://dx.doi.org/10.1016/i.colsurfa.2010.11.064

Wang, X.; Liu, R.; Shao, Z.; Miller, J. H.; Wakasiki, S.; Lisana, R. A new treatment technique of produced water from polymer flooding. In: IPTC 2014: International Petroleum Technology Conference. 2014. http://dx.doi.org/10.2523/iptc$\underline{17455-\mathrm{ms}_{\mathrm{s}}}$

Yan, N.; Masliyah, J. H. Demulsification of solidsstabilized oil-in-water emulsions. Colloids and Surfaces A: Physicochemical and Engineering Aspects, v. 117, n. 1, p. 15-25, 1996. http://dx.doi.org/10.1016/0927-7757(96)03639-4

Yongrui, P.; Zheng, Z.; Bao, M.; Li, Y.; Zhou, Y.; Sang, G. Treatment of partially hydrolyzed polyacrylamide wastewater by combined Fenton oxidation and anaerobic biological processes. Chemical Engineering Journal, v. 273, p. 1-6, 2015. http://dx.doi.org/10.1016/j.cej.2015.01.034

Ye, Z.; Gou, G.; Gou, S.; Jiang, W.; Liu, T. Synthesis and characterization of a water-soluble sulfonates copolymer of acrylamide and $\mathrm{N}$-allylbenzamide as enhanced oil recovery chemical. Journal of Applied Polymer Science, v. 128, n. 3, p. 2003-2011, 2013.

Zhang, L.; Xiang'an, Y.; Fenqiao, G. Micromechanisms of residual oil mobilization by viscoelastic fluids. Petroleum Science, v. 5, n. 1, p. 56-61, 2008. http://dx.doi.org/10.1007/s12182-008$\underline{0009-1}$ 
Zhang, L.; Zhuang, J.; Liu, H.; Li, H. M.; Zhao, Z. Terpolymerization and performance of 2-acrylamide-2-methyl propane sulfonic acid/itaconic acid/N-vinyl-2-pyrrolidone. Journal of applied polymer science, v. 117, n. 5, p. 29512957, 2010. http://dx.doi.org/10.1002/app.32222

Zhang, R.; Ye, Z.; Peng, L.; Qin, N.; Shu, Z.; Luo, P. The shearing effect on hydrophobically associative water-soluble polymer and partially hydrolyzed polyacrylamide passing through wellbore simulation device. Journal of Applied Polymer Science, v. 127, n. 1, p. 682-689, 2013. http://dx.doi.org/10.1002/app.37853

Zhang, J.; Jing, B.; Tan, G.; Zhai, L.; Fang, S.; Ma, Y. Comparison of performances of different type of clarifiers for the treatment of oily wastewater produced from polymer flooding. The Canadian Journal of Chemical Engineering, 2015. http://dx.doi.org/10.1002/cjce.22216
Zhao, X.; Liu, L.; Wang, Y.; Dai, H.; Wang, D.; Cai, $\mathrm{H}$. Influences of partially hydrolyzed polyacrylamide (HPAM) residue on the flocculation behavior of oily wastewater produced from polymer flooding. Separation and Purification Technology, v. 62, n. 1, p. 199-204, 2008.

http://dx.doi.org/10.1016/i.seppur.2008.01.019

Zheng, F. F.; Quiroga, P.; Sams, G. Challenges in processing produced emulsion from chemical enhanced oil recovery-polymer flood using polyacrylamide. In: SPE Enhanced Oil Recovery Conference. Society of Petroleum Engineers, 2011. http://dx.doi.org/10.2118/144322-ms

Zhong, C.; Huang, R.; Zhang, X.; Dai, H. Synthesis, characterization, and solution properties of an acrylamide-based terpolymer with butyl styrene. Journal of applied polymer science, v. 103, n. 6, p. 4027-4038, 2007.

http://dx.doi.org/10.1002/app.25546 